\title{
Organization and reorganization preoccupy Canada's scientists
}

\begin{abstract}
THROUGH the kindness of George Connell, the president of the University of Toronto, Nature was able to hold a consultation with officials, academics and working scientists at an afternoonlong seminar on the university campus. Much of the conversation informs the accompanying pages; what follows here is a brief account of the issues that appear to be at the front of the research community's mind. Attending were Maurice L'Abbé (Science and Technology Council of Quebec), George Connell (University of Toronto), Michael R. Hayden (University of British Columbia), Tom Jukes (University of California), Geraldine KenneyWallace (Science Council of Canada), Gordon Maclachlan (McGill University), Arthur May. (Natural Sciences and Engineering Research Council), Arnold Naimark (University of Manitoba), John Polanyi (University of Toronto), Mark J. Poznansky (University of Alberta), Scott Tremaine (Canadian Institute for Theoretical Astrophysics), J. Tuzo Wilson (University of Toronto) and from Nature, John Maddox (Editor), Alun Anderson (Washington Editor) and Joseph Palca (US News Editor).
\end{abstract}

IN the old days, Canadian science was almost synonymous with the National Research Council (NRC). Tuzo Wilson, the geophysicist, explained why that should have been the case; NRC became the residual legatee of the great excitement of Canada's contribution to the Second World War, as a safe base both for general defence research within the British Commonwealth and, before Pearl Harbor, for the British contribution to the eventually joint development of nuclear weapons.

The momentum was sustained, after 1945, with the development of the CANDU reactor, the continuing influence of the Defence Research Board, and the strength

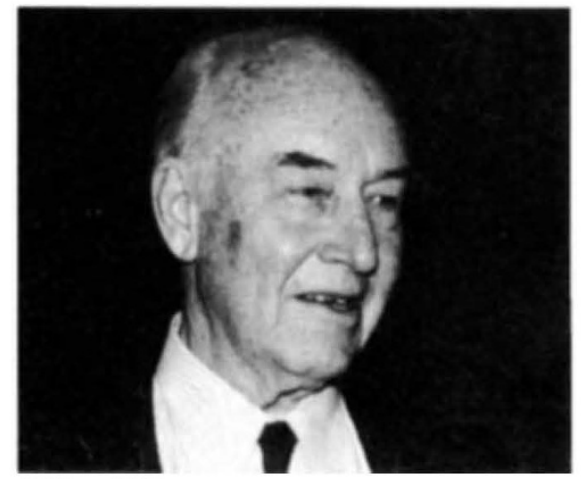

J. Tuzo Wilson.

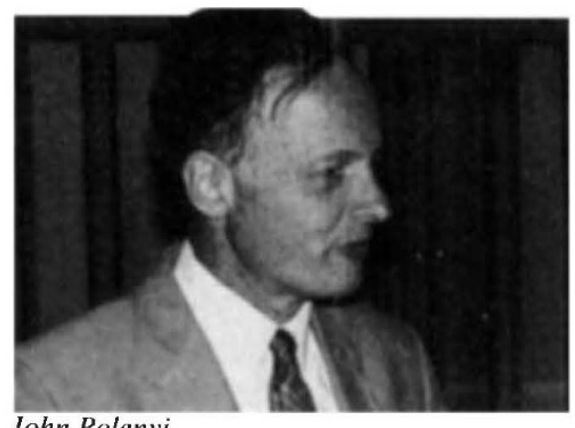

John Polanyi.

of G.A. Herzberg's spectroscopy research laboratory at Ottawa, in all of which NRC had an influential hand. Some of NRC's riches trickled as research grants to university groups, but like crumbs from rich men's tables. In less than a quarter of a century, NRC had become an overpowerful paternalistic Goliath, puzzled that its good intentions were so often misunderstood, until a Trudeau government cut it down to size.

Canada has been searching for a comfortable organization ever since Events have not been conducive to success. Reorganization has coincided with the growth of regional self-consciousness, which explains why some insist on the importance of networks among academic researchers as a means of demonstrating that inter provincial collaboration is a reality and why others say flatly that networks are a sham, a device for winning a cosmetic benefit at the cost of efficiency and the concentration of inadequate resources on outstanding research groups.

The shortage of money, every research community's first complaint, takes a distinctive form in Canada. What funds there are for academic research are overequitably spread, with the result that researchers find themselves supported with grants that are perhaps a sixth of what their competitors south of the border are awarded by agencies such as the US National Institutes of Health (NIH). Yet the device of applying directly for NIH support often requires a demeaning deal with a US research group.

Quite apart from the political pressure in favour of inter-provincial equality, there seems no general agreement on the principles on which resources might be concentrated. The federal government and its advisers favour concentration on national needs - energy. resource development and the like. But some would rather concentrate on fields in which Canadian researchers have made an international mark (such as recent successes in the identification of genes responsible for inherited diseases) and others (such as John Polanyi) would concentrate instead on outstanding people. Yet the support mechanisms, especially those by which federal dollars match what researchers are able to recruit from industry, imply that academics often resent the way their work is biased by industry's conception of its own needs.

What are the chances that these discontents will melt away under the influence of enlightened policies yet to be enacted? One surprising undertone of this consultation was what seemed to be a general sympathy for the federal government's predicament. The shortage of funds seems to be generally appreciated, as is the difficulty of working out a strategy for the years ahead. Some of the thrashing around of the past two decades would have been more severely criticized than it was at Nature's seminar if people were more inclined to believe the federal government to be malign rather than lost.

It may have helped to blunt the edge of criticism that the newly appointed chairman of the Science Council of Canada, Dr Geraldine Kenney-Wallace, is a regular academic (from Toronto) who, however
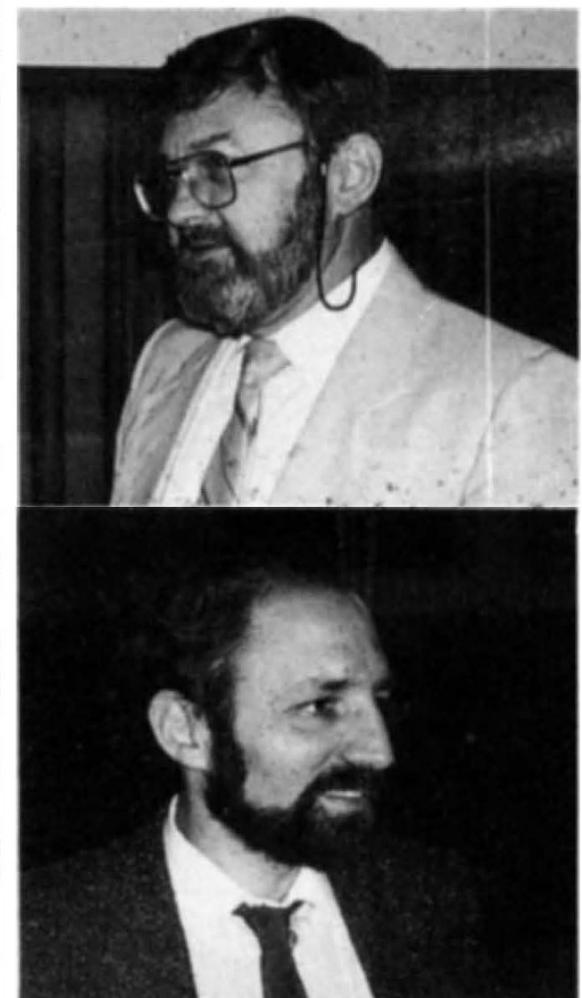

Arthur May (top) and Michael R. Hayden.

controversial her business may be, retains a kind of academic articulateness and independence. Indeed, one could almost hear the Canadian participants in our consultation catch their breath when she gave us to understand that if she found the bureaucracy cramping her freedom of action, she would simply quit, going back to being a simple chemist. If she can win the trust of her natural constituents, Canada's grant-holders and academics, she may find that she never has to take that fateful step.
John Maddox 